\title{
CENTENARY OF THE BIRTH OF THE FAMOUS UKRAINIAN RESEARCHER OF RADIOMETEORS PROF. B.L.KASHCHEYEV (1920-2004), HIS HERITAGE AND TRAJECTORY MEASUREMENTS TODAY
}

\author{
S.V. Kolomiyets, K.A. Kolomiiets, I.Yu. Kyrychenko, Yu.D. Pryimachov \\ Kharkiv Nationnal University of Radio Electronics \\ 14 Nauky ave., Kharkiv, Ukraine, svitlana.kolomiyets@nure.ua
}

\begin{abstract}
The development of meteor radar research was stimulated during World War II by air defense requests to rule out false alarms of radars on meteoroid intrusions. After the war, many air defense radars were involved in scientific observations of meteors. An additional stimulus for interest in the study of radiometeors was the phenomenon of the Draconid meteor shower in 1946, which was recorded by the radio method as extraordinary. We can talk about the
\end{abstract} scientific and technological revolution of this period, associated with the use and boom in the development of radio technology and missile technology. The ballistics of the movement of airborne objects in the Earth's atmosphere (and outside the atmosphere since 1957) of artificial and natural origin is becoming increasingly complex. Radio technology could not have developed without knowledge of the ionosphere and the effects of the Sun on radio communications, along with the effects of the Sun on the ionosphere. In the ionosphere, a layer at altitudes of $70-130 \mathrm{~km}$ is called the meteor zone, i.e. the zone where cosmic bodies, burning in the Earth's atmosphere, cause the appearance of ionized meteor tracks, which interact with radar radiation and reflect it. This allows the radar receiver to record the reflected signal. In the presence of three receivers spaced 3-5 $\mathrm{km}$ apart (and located approximately at the vertices of a right triangle), it is possible to determine the guiding cosines of the trajectory of the meteoroid in the Earth's atmosphere. Continuing the trajectory of the meteoroid to the intersection with the celestial sphere at infinity, we obtain a point called the meteor radiant. In basic optical meteor observations, the trajectory is determined differently than in the radio method. The article highlights the significance of the event of the centenary of the birth of the famous Ukrainian researcher of radiometeors Prof. Kashcheyev B.L.(1920-2004) and its legacy, as well as the problems and solutions of trajectory measurements today.

Keywords: meteors, ionosphere, trajectory measurements, meteor radar, Kashcheyev heritage.
АНОТАЦІЯ. Розвиток метеорних радіолокаційних досліджень було стимульовано під час другої світової війни запитами протиповітряної оборони на виключення хибних спрацьовувань радарів на метеороїдні вторгнення. Після закінчення війни багато радарів протиповітряної оборони були залучені до наукових спостережень за метеорами. Додатковим стимулом інтересу до дослідження радіометеорів стало явище метеорного доща Драконід в 1946 році, яке саме було зафіксоване радіометодом як надзвичайне. Можна казати про науково-технічну революцію цього періоду, пов'язану з застосуванням та бумом розвитку радіо технологій та ракетних технологій. Балістика руху повітряних об'єктів в атмосфері Землі (і за межами атмосфери з 1957) штучного та природного походження стає пов'язаною зі все більш складними задачами. Радіотехнології не могли розвиватися без знань про іоносферу і про вплив Сонця на радіо зв'язок разом з наслідками сонячного впливу на іоносферу. В іоносфері виділяється прошарок на висотах 70-130 км під назвою метеорна зона, тобто зона, де космічні тіла, згоряючи в Земній атмосфері викликають появу іонізованих метеорних слідів, які взаємодіють $з$ падаючим на них випромінюванням радіолокаторів та віддзеркалюють його. Це дає змогу зафіксувати відбитий сигнал приймачем радіолокатора. При наявності трьох приймачів, рознесених у просторі на 3-5 км (та розташованих приблизно у вершинах прямокутного трикутника) можна визначити направляючі косинуси траєкторії руху метеороїда в атмосфері Землі. Продовжуючи траєкторію руху метеороїда до перетину 3 небесною сферою на нескінченності ми отримуємо точку, яка зветься метеорним радіантом. При базисних оптичних метеорних спостереженнях визначення траєкторії проводиться інакше, чим при радіометоді. Стаття висвітлюе значення події сторіччя від дня народження відомого українського дослідника радіометеорів проф. Кащеєва Б.Л. (1920-2004) та його спадщини, а також проблеми i рішення траєкторних вимірювань сьогодні. 
Ключові слова: метеори, іоносфера, траекторні вимірювання, метеорний радар, спадщина Кащеєва.

\section{Introduction. Researcher B.L. Kashcheyev}

Science of the XXI century, in particular, related to the study of meteors, has its own special history with a powerful layer of the Ukrainian scientific and technical heritage of the XX century in this area. An important milestone in this history is 1957 and the associated program of the International Geophysical Year (IGY-1957) and the fifth section of this program "Ionosphere. Meteors" (Hocking \& Kolomiyets, 2020; Kolomiyets et al., 2016; Tsesevich, 1957). In this section, the best world-level results in meteor radar studies were obtained by the Kharkiv scientific group of meteor researchers headed by B.L. Kashcheyev and with his direct participation (Lebedev \& Sollogub, 1960). The significant contribution of B.L. Kashcheyev to the IGY-1957 program was awarded a certificate and badge "Gold IGY-1957" in connection with the fiftieth anniversary of the IGY 1957 program in 2007 (Kolomiyets et al., 2016). Kashcheyev B.L. (1920-2004) - a famous Ukrainian scientist, Honored Scientist of Ukraine, Professor, Doctor of Technical Sciences, Honorary Professor of the Kharkiv National University of Radio Electronics. He organized and directed the Kharkiv radar meteor research, starting with the registration of radiometeors for the first time in Ukraine in Kharkiv in 1954 for almost fifty years (Kolomiyets, 2012).

Meteor Scientific Group led by B.L. Kashcheyev began to conduct meteor research at the Kharkiv Polytechnic Institute (KhPI), and in July 1971 one was transferred to the Kharkiv National University of Radio Electronics (NURE) as part of the Department Fundamentals of Radio Engineering together with the Balakliia observatory base.

In 2021 it will be 50 years since the beginning of the deployment of research under the leadership of B.L. Kashcheyev within the walls of the NURE on scientific research meteor topics, including in the field of meteor radio astronomy (Kolomiyets, 2012). In 2007, the meteor radio astronomy direction was formalized in a separate research laboratory of radio astronomy named after B.L. Kashcheyev inside the scientific research department of NURE. In the name of B.L. Kashcheyev also named asteroid 6811 in 2000 (Kolomiyets et al., 2016). The merits of B.L. Kashcheyev as the organizer of science and a high rating of world-class scientific achievements of the team of scientists of NURE under his leadership, not only in the field of meteor radio astronomy, but also in the field of meteor geophysics, as well as in the applied aspects of meteor research. The encyclopedia "Names of Ukraine in Space" (Kolomiyets, 2003) confirmed the fact that the names of three minor planets are associated with the University of NURE. In addition to the asteroid "Kashcheev" there are also the asteroids "KhTURE" and "Voloshchuk". This underlines the significant world-class contribution to science made by the research meteor department of the University under the leadership of B.L. Kashcheyev, as well as the role of the University in creating opportunities for B.L. Kashcheyev and his scientific group. Significant monographs co-authored by B.L.Kashcheyev, contain theoretical and experimental developments, here we note the following: "Meteor phenomena in the atmosphere of the Earth", 1967 (Kashcheyev et al., 1967), "Meteors and meteor substance", 1989 (Voloshchuk et al., 1989). B.L. Kashcheyev, together with the scientific team headed by him, along with achievements in theoretical research, had world recognition in conducting meteor experiments (Kolomiyets, 2012; Kashcheyev \& Tkachuk, 1980; Novoselova \& Tkachuk, 1971). Meteor radar systems of several generations created under his leadership, including MARS (Meteor Automated Radar System) of the period 1968-1978, have always been at the level of world standards or exceeded world standards. In 2004, the one of the modification of the NURE MARS, updated under the leadership of B.L. Kashcheyev at the end of the twentieth century was included in the list of objects of national heritage of Ukraine under the name "Multipurpose geophysical complex for studying the atmosphere and the influx of meteor matter", Balakliia district(List of objects that make up the national heritage - NAS of Ukraine 2013).

In 1968-1970 B.L. Kashcheyev with the scientific team from Kharkiv together with P.B. Babadjanov and the scientific team from Dushanbe carried out meteor scientific experiments in Somalia, Mogadishu. This event was named the Soviet Equatorial Meteor Expedition. Meteor observations at the equator were made for the first time in the world (Catalog, 1975). The name of B.L.Kashcheyev is inseparable from the most significant geophysical projects of the second half of the 20th century. The IGY-1957 project mentioned above was, among other things, the first global project of joint experiments in the field of geophysics and astronomy (Tsesevich, 1957) on the widest range of topics with measurement research inclusive. These joint astronomical and geophysical studies were continued in the project under the previous program called "International Geophysical Cooperation 1959" (Lebedev \& Sollogub, 1960; Kashcheyev \& Tsesevich, 1965; Ovezgeldyev et al., 1986).

The level of meteor research in Kharkiv was very high, which made it possible to consider and solve the issues of the methodology of radiometeor observations (Kashcheyev \& Nechitaylenko, 1983), create models, including engineering ones (Andreev et al., 1987), and make progress in applied aspects (Kashcheyev et al., 1996). 


\section{Trajectories. Meteors. Ballistics}

According to (Astapovich, 1958) et al. the visible meteor trajectory on a sphere is the segment of its path between the points of appearance and disappearance of the meteor, usually expressed in degree. The true trajectory of a meteoroid is called a segment of the path in space, between the corresponding points in the Earth's atmosphere. The trajectory of a meteoroid relative to an observer on the Earth's surface is called atmospheric or topocentric, relative to the center of the Earth - geocentric, with respect to the Sun - a heliocentric trajectory (orbit). Determination of the orbit (trajectory) of meteoroids, which they describe around the Sun as small bodies of the Solar system, is based on observations of a small part of their path (trajectory) that they cover in the Earth's atmosphere. A meteor phenomenon accompanying the movement of a meteoroid in a certain part of its path in the Earth's atmosphere (meteor zone) is observed by us for a very short time. If it is possible to obtain from observations the velocity of the meteoroid in magnitude and direction, the problem of finding its orbit will be solved, since the coordinates of the meteoroid relative to the Sun are known: they are determined by the position of the Earth at the time of observation. Trajectory elements for each type of trajectory have a special terminology.

In general, the problem of the motion of a meteoroid in the Earth's atmosphere in the range of Earth's speeds and in narrower applications is considered a problem of external ballistics. One of the special tasks of ballistics - the movement of a rocket, the mass of which decreases - is mathematically identical to the problem of the movement of a meteor body, and even then with reservations (for certain altitude intervals above sea level, for a meteoroid that retains part of its mass, etc.). For practical convenience, the motion of a meteoroid is distinguished in several sections of its trajectory in the Earth's atmosphere: higher, upper, middle, low and lower. The physical theory of meteors describes the physical processes accompanying the entry of a meteor body into the Earth's atmosphere: glow and ionization of the atmosphere, reflection of radio waves from a meteor trail (Levin, 1956; Kashcheyev et al., 1967; Voloshchuk et al., 1989).

The first "artificial meteors" were projectiles and bullets (for example, experiments with high-speed bullets were carried out in the Astroballistics Laboratory of the US Navy (Astapovich 1958), appeared others technologies for laboratory studies of high-speed movement of objects (i.e., with speeds of $3-90 \mathrm{~km} / \mathrm{s}$ ). The velocity of the meteoroid in the Earth's atmosphere is $11-72 \mathrm{~km} / \mathrm{s},(39,000-259,000 \mathrm{~km} / \mathrm{h})$. The maximum speed of the projectiles can reach $0.3 \mathrm{~km} / \mathrm{s}(1000$ $\mathrm{km} / \mathrm{h})$. The speed of sound in air is $340 \mathrm{~m} / \mathrm{s}(0.34$ $\mathrm{km} / \mathrm{s}$ or $1.224 \mathrm{~km} / \mathrm{h}$ ). The North American X-15 was a hypersonic rocket-powered aircraft operated by the United States Air Force and the National Aeronautics and Space Administration as part of the X-plane series of experimental aircraft. As of September 2015, the X15 holds the official world record for the highest speed ever recorded by a manned, powered aircraft. It could reach a top speed of $2 \mathrm{~km} / \mathrm{s}$ (7.274 km per hour).

Important information about the laws of motion of meteoroids can be gleaned from meteoritics, the science of meteorites and cosmic dust falling onto the Earth's surface. This branch of astronomy studies the movement of meteor bodies and their interaction with the atmosphere when cosmic matter falls to the Earth. Scientific research in meteoritics includes the collection, identification, and classification of meteorites and the analysis of samples taken from them in a laboratory. One of the main tasks of meteoritics is to find a dropped object. Annually, about 100 thousand tons of meteor bodies invade the Earth's atmosphere, among them about 800 (Kruchinenko, 2012) fall in the form of meteorites.

Numerical methods, analytical solutions using a modern computer base, modeling in the study of the movement and destruction of meteoroids and fireballs in the Earth's atmosphere in the form of information technologies have long been an integral part of meteor science (Moreno-Ibáñe, 2020; Dmitriev, 2015; Bouquet et al., 2014; Clark \& Wiegert, 2011; Ceplecha, 1987). One of the new methods is determining the fate of the fireball using the $\alpha-\beta$ criterion (Sansom et al., 2019).

Fireball networks, which are particularly effective at detecting meteorites, have become another technology to improve the methods and means of observing meteors. Now successful meteor networks of amateurs and professionals are deployed in the USA and Canada (CAMS, CMN etc. (Gural, 2012)), Japan (SonotaCo), Europe (Fripon).

Among the observational methods of meteor astronomy (visual, optical/photographic, television, etc./, radar, "in suty" and others) from the point of view of trajectory measurements, we distinguish two types: 1) optical methods, connecting to them visual, 2)radar methods. One of the main tasks of observational meteor astronomy is to determine the orbit of a meteor body through the parameters of the trajectory in the Earth's atmosphere. An important parameter of the movement of a meteoroid is the meteor radiant (a point on the celestial sphere). In optical methods, the trajectory of a meteoroid in the Earth's atmosphere is recorded as a projection onto the celestial sphere in the form of an arc of the celestial sphere (Astapovich, 1958). Special techniques have been developed for determining the parameters of the meteor trajectory by optical methods (Astapovich, 1958), where the deter- 
mination of the coordinates of the meteor radiant precedes the determination of other parameters of movement. In the radar method, the direction cosines of the trajectory in the Earth's atmosphere are determined first, and secondly, the coordinates of the meteor radiant (Kashcheyev et al., 1967). The fundamental difference between radar observations and optical ones is that during optical observations the energy emitted by the meteor is recorded, and during radar observations the electromagnetic energy of the transmitter of the radar station reflected or scattered by the electrons of the meteor trail is recorded. The parameters of the Kharkiv meteor radar "MARS II" in the period 19721978 are as follows (Table 1):

Table 1: Ratings MARS II

\begin{tabular}{|l|l|}
\hline Operating frequency/ & $31.1 \mathrm{MHz}$ \\
wavelength & $9.6 \mathrm{~m}$ \\
Pulse Transmitter Power & up to $1 \mathrm{MW}$ \\
Pulse Repetition Rate & $500 \mathrm{~Hz}$ \\
Pulse duration & $30 \mathrm{kgB} \cdot \mathrm{m} / \mathrm{s}$ \\
Antenna type (main antennas) & Corner \\
Antenna gain coefficient, & $\sim 250 / 16$ \\
(main/remote) & \\
Direction,altitude,latitude,longitude & east, $45^{\circ}, 5^{\circ}, 30^{\circ}$ \\
Minimum detectable receiver signal & $5 \mu V^{11} \mathrm{em}^{-1}$ \\
Type of registered meteor trails & $\sim 10^{-6} \mathrm{~g}$ \\
Minimum detectable mass & $\sim 10^{-6}$ \\
\hline
\end{tabular}

The principles of construction and a complete description of MARS are given in (Kashcheyev et al., 1977). MARS was a multidisciplinary observation tool and made it possible to solve diverse problems of geophysics and astronomy (Fedynsky et al., 1976). The capabilities of MARS in trajectory measurements were as follows. The meteor radar determined and printed 37 parameters of the meteoroid motion and related characteristics, including: 1) the orbit of the meteoroid; 2) slant range: 3 ) time; 4) velocity; 5) time shifts of the signal at remote points in relation to the main point; 6 ) azimuth and zenith angle of the radiant; 7) the height of the meteor (the height of the reflecting point on the trail); 8) the elevation angle of the reflecting point. Additionally, a separate study was devoted to altitude measurements (Novoselova \& Tkachuk, 1971).

Observational experiments in Kharkiv (at an observation base near Balakliia) for almost 40 years after 1957 left behind a legacy in the form of radiometeor databases (digitized and not digitized). The digitized base of radiometeor data from 1972-1978 (Voloshchuk et al., 2018) can be used as a research tool for various tasks. Let us demonstrate this for studying the motion of meteor bodies with a velocities of less than 23 $\mathrm{km} / \mathrm{s}$. These are the velocities inherent in meteorites (Levin, 1957). Fig. 1 shows an illustration of the theoretical meteorite collection cone according to (Simonenko, 1975). Meteorites vary greatly in size. Most of

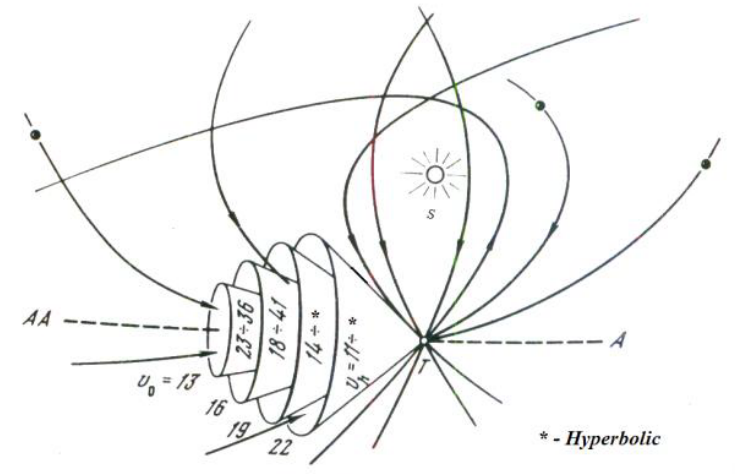

Figure 1: "Cones of collection" of meteorites.

the meteorites have a mass of several grams to several tens of tons. There are micrometeorites too.

A meteor that reached $+1 \mathrm{M}$ at a speed of $40 \mathrm{~km} / \mathrm{s}$, appeared at an altitude of $100 \mathrm{~km}$, and disappeared at an altitude of $80 \mathrm{~km}$ at a distance of $150 \mathrm{~km}$ from the observer, will have a flight time of 1.5 seconds, a size of $0.6 \mathrm{~mm}$ and a mass of $6 \mathrm{mg}$. The permeability of photographic methods is limited by meteors $+4 \mathrm{M}$. Television and electro-optical instruments make it possible to increase the sensitivity of the method, for example, the Dushanbe data (Narziev, 2019) refer to meteors brighter than $+5 \mathrm{M}$. Radar techniques provide even more opportunities for observing weaker meteors, i.e. to conduct research on meteoroids with lower masses. In the 70s information about weaker meteors (from $+6.5 \mathrm{M}$ to $+13 \mathrm{M})$ in Harvard, Obninsk, Kharkiv and Kazan was obtained by the radar method. The features of the influx of meteor substances into the Earth's atmosphere are well demonstrated in Fig. 2, credit (Ceplecha, 1998), which shows the complexity of this process. The Kharkiv MARS in 1972-1978 recorded an influx of meteor substance in the mass range $10^{-6}-10^{-3}$ $\mathrm{g}$, it was considered one of the most highly sensitive radars in the world, as it recorded the orbits of radiometeors up to $+12 \mathrm{M}$, and the number of radiometeors up to $+14 \mathrm{M}$. It is believed that the New Zealand meteor radar AMOR, when registering meteor orbits, had a sensitivity of up to $+13 \mathrm{M}$, although the reliability of these data is possibly somewhat lower compared to the Kharkiv data. The currently active orbiting meteor radars CMOR (Canada) and SAAMER (Tierra del Fuego, Argentina) have a sensitivity of up to $+8 \mathrm{M}$.

\section{Results and discussion}

What can the Kharkiv meteor data tell about meteorites in such a difficult situation with the meteor substances influx into the Earth's atmosphere and why? Kharkiv meteor data are statistically secured and reliable. Meteoroids from any mass range are part of the 


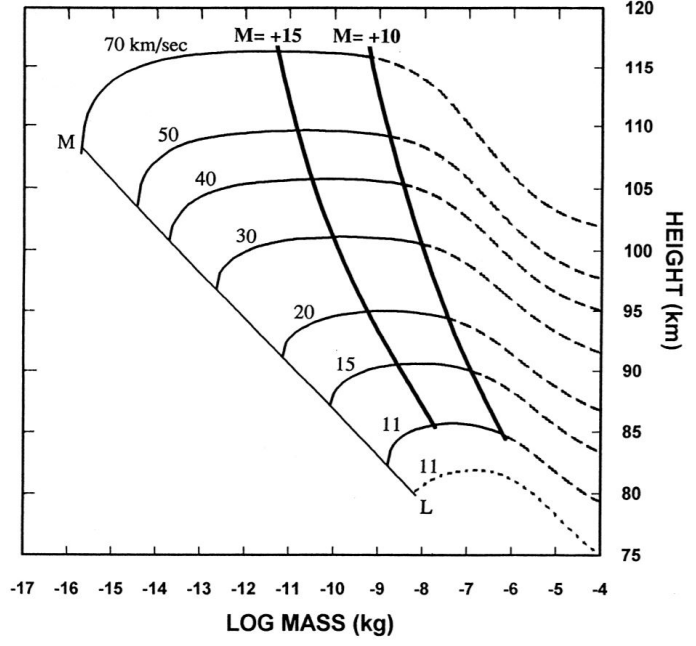

Figure 2: Credit (Ceplecha, 1998), Heights of meteor ablations as a function of mass and velocity

world around us and carry partial information about this world. It remains only to correctly extract this information. In meteor astronomy, the techniques and methods of probability theory and mathematical statistics are widely used, the representativeness of samples is taken into account. In meteor astronomy, the distributions of the number of cases are analyzed for selected parameters. The trajectories of objects from the class of the Solar system small bodies and the laws of their motion are closely related. The bodies falling to the Earth are endowed with general patterns in their orbital dynamics. For smaller bodies, the statistical security is higher and, therefore, a higher probability of establishing a pattern. From the aforementioned Kharkiv meteor database, we selected for analysis meteoroids in the amount of about 160,000 pieces, for which orbits were determined. Also, other samples from this database were used, first of all, a sample of meteoroids orbits with velocities characteristic of meteorites was taken, i.e. $\mathrm{Vg}<23 \mathrm{~km} / \mathrm{s}$. Fig. 3 shows the distribution of the number of orbits by parameters: a) $\mathrm{N}=\mathrm{N}(\mathrm{Vg})$ for $\mathrm{Q}>100 \mathrm{AU}$ (among 159318), b) $\mathrm{N}=\mathrm{N}(\mathrm{Nu}, \mathrm{Vg}$ ) for 1978 (all orbits); c) $\mathrm{N}=\mathrm{N}(\alpha, \delta)$ for $\mathrm{Q}<1.5$ and $\mathrm{Vg}<23 \mathrm{~km} / \mathrm{s}$ (denote the Near Earth environment); d) $\mathrm{N}=\mathrm{N}(\mathrm{Nu}, \mathrm{Vg})$ for $\mathrm{Q}<1.5$ and $\mathrm{Vg}<23$ $\mathrm{km} / \mathrm{s} ;$ e) $\mathrm{N}=\mathrm{N}(\alpha, \delta)$ for $1.5<\mathrm{Q}<3.8$ and $\mathrm{Vg}<23 \mathrm{~km} / \mathrm{s}$ (denote the Asteroids Main Belt); d) $\mathrm{N}=\mathrm{N}(\mathrm{Nu}, \mathrm{Vg}$ ) for $1.5<\mathrm{Q}<3.8$ and $\mathrm{Vg}<23 \mathrm{~km} / \mathrm{s}$.

By analyzing the specified database of meteor data, we have established the following patterns. In Fig. 3, a we see that the orbits of meteoroids with $\mathrm{Vg}<$ $23 \mathrm{~km} / \mathrm{s}$ may have aphelions Q exceeding $100 \mathrm{AU}$ (Kolomiyets, 2018); the distribution of the number of orbits over the coordinates of the radiant for the selected areas of their aphelions near the Earth and
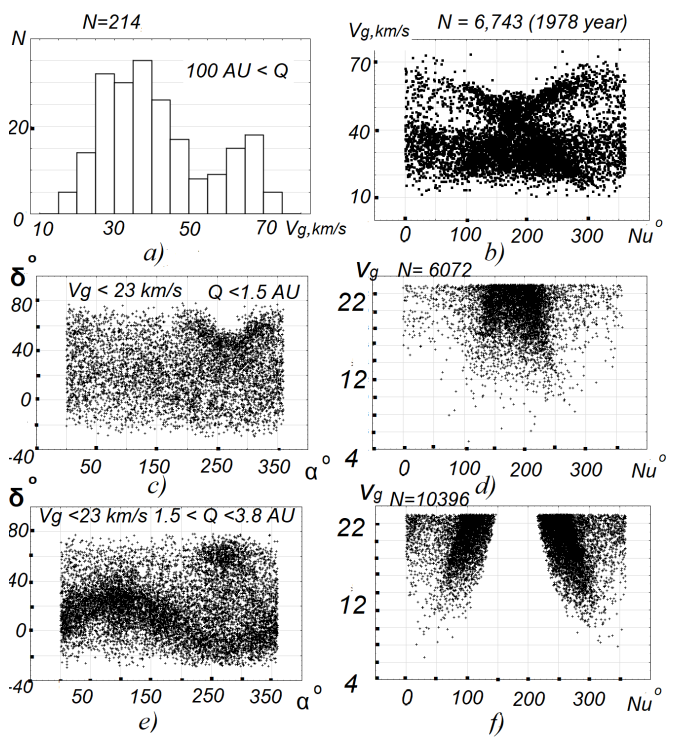

Figure 3: Distribution of the number of orbits of meteoroids according to the selected parameters, including under the condition $\mathrm{Vg}<23 \mathrm{~km} / \mathrm{s}$ (c-f).

near the Main Belt of Asteroids have specific features. It turned out that all the orbits of meteoroids with $\mathrm{Vg}$ $<23 \mathrm{~km} / \mathrm{s}$ have an inclination less than 90 degrees (e.g. Fig. 4, d). The distributions of orbital elements (eccentricity, argument of perihelion, perihelion distance, inclination) for the selected areas of their aphelions near the Earth and near the Main Belt of Asteroids have the following course (Fig. 4, a-d, Q $<$ $1.5 \mathrm{AU}$ - white (top) and $1.5<\mathrm{Q}<3.8 \mathrm{AU}$ - gray (bottom), respectively). The concept of the meteor sky, set forth in (Kolomiyets, 2018), was used for a differentiated study of the orbital dynamics of small bodies in the Solar System from the meteor statistics of the database with the selected parameters.

\section{Conclusion}

The purpose of this research was: 1) to show that in the history of Ukraine there are facts indicating a significant contribution to world and national science of Kharkiv scientists under the leadership of B.L. Kashcheyev in the field of research of meteors by the radar method; 2) to demonstrate the existence of these achievements and the stages of their acquisition in connection with the centenary of the birth of B.L. Kashcheyev in 2020; 3) once again to point out the complexity of trajectory measurements in meteor science and other ballistics application, show different approaches to solving problems of the movement of meteoroids; 4) to use the statistical properties of the Kharkiv meteor database of weak radiometeors to study the orbital motion of space objects, incoming 


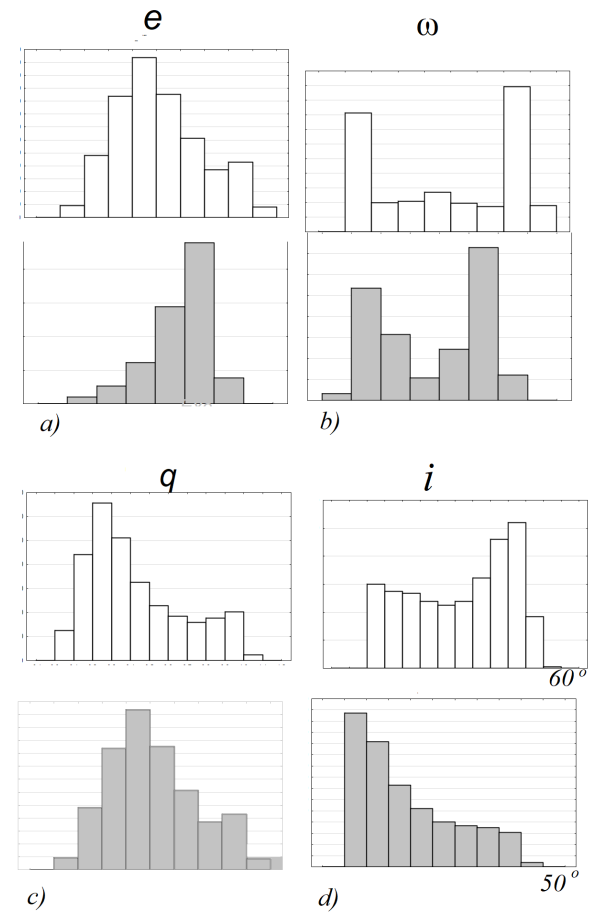

Figure 4: Distributions of meteor orbital elements for a sample of Near-Earth aphelions, aphelions in the Main Asteroid Belt and $\mathrm{Vg}<23 \mathrm{~km} / \mathrm{s}$

into the Earth's atmosphere with geocentric velocities less than $23 \mathrm{~km} / \mathrm{s}$, and others aspects. It was found that in the studied meteor database for the sample $\mathrm{Vg}<23 \mathrm{~km} / \mathrm{s}$, there are no orbits with reverse motion (i.e., there are no orbits with inclination $\mathrm{i}>90^{\circ}$ ), and the aphelions distances of their orbits may have values from 0.98 to $100 \mathrm{AU}$ and higher.

\section{References}

Andreev V.V., Babadzhanov P.B., Barsukov V.L. et al.: 1987, GOST 25645.128-85. Meteor substance, spatial distribution model, M.: Izd. standartov, $23 \mathrm{p}$.

Astapovich I.S.: 1958, Meteor phenomena in the atmosphere of the Earth, M.: Fizmatgiz, 640 p.

Bouquet A., Baratoux D., Vaubaillon J. et al.: 2014, Planetary and Space Science, 103, 238.

Catalog: Dec. 1968 - Jul. 1970, Moscow, 1975, 167.

Ceplecha Z.: 1987, Bull. of the Astron. Inst. of Czechoslovakia, 38, 222.

Clark D., Wiegert P.: 2011, Meteorit. Planet. Sci., 46, 1217.

Gural V.P.: 2012, Planetary Science, 9, 1405.

Dmitriev V., Lupovka V., Gritsevich M.: 2015, Planetary and Space Science, 117, 223.

Hocking W.K., Kolomiyets S.V.: 2020, Radiotekhnika: All-Ukr. Sci. Interdep. Mag., 201, 78.

Fedynsky V.V., Kashcheyev B.L., Voloshchuk Yu.I. et al.: 1976, Bull. of the USSR Academy of Sciences, 10, 89 .
Jenniskens P. S., Gural L., Dynneson B. J. et al.: 2016, Icarus, 40.

Kashcheyev B.L., Koval Yu.O., Gorbach V.I. et al.: 1996, Meteors today, K.: Tekhnika, 196 p.

Kashcheyev B.L., Nechitaylenko V.A.: 1983, Meteor research, $\mathbf{8}$.

Kashcheyev B.L., Lebedinets V.N., Lagutin M.F. et al.: 1967, Meteor phenomena in the Earth's atmosphere, M.: Nauka, 260p.

Kashcheyev B.L., Tkachuk A.A.: 1980, Catalogue of meteor orbits to +12M, Moscow, $232 \mathrm{p}$.

Kashcheyev B.L., Tsesevich V.P.: 1965, The study of circulation of atmosphere in the meteor zone. Instcuction manual, M.: Nauka, 64 p.

Kashcheyev B.L., Voloshchuk Yu.I., Dudnik B.S. et al.: 1977, Meteor research, 4, 11.

Kolomiyets S.V.: 2012, IEEE, 46.

Kolomiyets S.V.: 2018, in: Proc. of the IAU Simposium 339, New York, 14, 215.

Kolomiyets S.V.: 2003, Scientific-encyclopedic vision /Ed. I.B. Vavilova \& Plachinda, Lviv, Kyiv, 654 p.

Kolomiyets S.V., Voloshchuk Yu.I., Slipchenko M.I. et al.: 2016, Radiotekhnika, 184, 6 .

Kruchinenko V.G.: 2012, Mathematical and physical analysis of the meteoric phenomenon: monograph, MAO NASU, K.: Nauk. Dumka, 294 p.

Lebedev T.S., Sollogub V.B.: 1960, Informatsionnyy byulleten' (Newsletter), $\mathbf{2}, 3$.

Levin B.Yu.: 1956, Physical theory of meteors and meteoric matter in the solar system, Publ. house of the Academy of Sciences of the USSR, $293 \mathrm{p}$.

List of objects that make up the national heritage: 2013, NAS of Ukraine [Electronic resource].

Moreno-Ibáñe M. et al. 2020, MNRAS, 494, 316.

Narziev M.: 2019, Planetary and Space Science, 173.

Novoselova N.V., Tkachuk A.A.: 1971, Radiotekhnika, 16, 18.

Ovezgeldyev O.G., Kashcheyev B.L., Nechitaylenko V.A. et al.: 1986, Radiotekhnika, 9, 83.

Sansom et al.: 2019 ApJ, 885, 115.

Sidorov V.V., Kolomiyets S.V.: 2007, in: Proc. IEU SS5 Cambridge Univ. Press, 189.

Simonenko A.N.: 1975, Atlas, 68.

Tsesevich V.P.: 1957, International Geophysical Year [1957-1958], M.: Gostekhizdat, 184 p.

Tsesevich V.P.: 1957, Astronomical problems of the International Geophysical Year, M.: Znanije, 40 p.

Voloshchuk Yu.I., Kashcheyev B.L., Kruchinenko V.G.: 1989, Meteors and meteor substance, K.: Nauk. dumka, 296 p.

Voloshchuk Yu.I., Kolomiyets S.V., Cherkas Yu.V.: 2018, Analysis of data on the small bodies of the solar system using information radio technologies: Catalog of meteor orbits. monograph., 344. DOI:10.30837/978-966-659-249-4 Corpus ID: 213952314. 